\title{
URGING COTTON PLANTS TO OVERCOME THE SALT STRESS CONDITIONS IN THE RECLAIMED LAND USING A COMBINATION OF INNOVATIVE AGRICULTRAL FACTORS II-THE RELATIONSHIP BETWEEN YIELD AND SOME CHARACTERS IN EGYPTIAN COTTON
}

\author{
(Received:15.6.2011) \\ By \\ M. M. Rady and M .D .H. Dewdar* \\ Botany Department and * Agronomy Department, Faculty of Agriculture, \\ Fayoum University
}

\begin{abstract}
The technique of stepwise multiple regression and correlation analysis was employed to determine the contribution of the various traits to the variation in cotton yield. Data were obtained from yield trials carried out in El-Tahrir Province, El-Behera Governorate, Egypt. during 2009 and 2010 seasons. The mean squares of regression analysis were high for nine acceptance variables (traits), i.e., the number of leaves per plant, leaf area per plant, dry weight of leaves per plant, chlorophyll b, total carotenoids, phosphorus, iron, manganese and lint percentage out of eighteen ones. The total contribution of the previously mentioned traits over all variation in seed cotton yield per plant was $99.46 \%$. However, the residual effect of other nine traits reduced $0.54 \%$ of the total variation in cotton yield. Seed cotton yield was significantly positive and had the greatest values of correlation coefficients with the number of leaves per plant (0.980), leaf area per plant (0.974) and chlorophyll b (0.970). High increase in the range of performances was detected for nine mentioned traits due to the creation of variation via different treatments under study. Finally, as increased number of leaves per plant, leaf area per plant and chlorophyll b may induce positive impacts on cotton yield under salinity conditions.
\end{abstract}

Key words: cotton, regression and correlation analysis, salinity stress.

\section{INTRODUCTION}

Cotton is an important field crop in many developing countries especially in Egypt. The yield of the crop is dependent upon the environment in which it is grown and the management practices of the cropping system. Salinity is a major limiting factor in crop production in many regions of the world. Plant physiologists have found chlorophyll content to be a valuable tool for monitoring plant stress response. It has been widely applied to the assessment of chlorophyll index in crop plants such as corn, wheat, cotton, rice as well as other agricultural species (Patrick, 2007).

The chlorophyll content is useful for improving nitrogen and fertilizer management (Gitelson et al., 2003). Determination of the relationship of the chlorophyll trait, yield and yield components facilitates selection of high yielding varieties (Singh, 2001).

Regression and correlation study is important to assistant cotton breeders. Therefore, it is necessary to determine the relationship between cotton yield and the various factors contributing to seed cotton yield per plant. Fonseca and Paterson (1968) found that the correlation coefficient analysis measures, the magnitude of relationship between various plant characters, the component character on which selection, can be based for improving seed cotton yield. The technique of stepwise multiple regression analysis has been extensively used by El-Shear et al. (1984), Seyam et al. (1984) and Ghaly et al. (1990). The present study used the regression and correlation analysis of cotton traits, for the information of interrelationship between cotton yield and other important traits, to determine the traits accounted for most of the variation in yield under salinity stress conditions.

\section{MATERIALS AND METHODS}

This study was conducted in the Experimental Field of El-Tahrir Province, El-Behera Governorate, Egypt during 2009 and 2010 seasons 
to find out the regression and correlation of seed cotton yield with various physiological traits under salinity stress conditions. Before sowing, soil samples to $30 \mathrm{~cm}$ depth from the experimental site were collected and analyzed by the standard procedures of Jackson (1967). Analysis results of the soil samples are presented in (Table 1).

Table (1): Physical and chemical properties of the selected site in both seasons.

\begin{tabular}{|c|c|c|}
\hline Property & 2009 & 2010 \\
\hline \multicolumn{3}{|l|}{ Physical: } \\
\hline Clay\% & 24.70 & 23.50 \\
\hline Silt\% & 22.10 & 23.90 \\
\hline Sand $\%$ & 53.20 & 52.60 \\
\hline Soil texture & Loamy sand & Loamy sand \\
\hline \multicolumn{3}{|l|}{ Chemical: } \\
\hline $\mathrm{pH}(1: 2.5)$ & 7.900 & 7.750 \\
\hline $\left.\mathrm{ECe}(\mathrm{dS} \mathrm{m})^{-1}\right)$ & 10.930 & 10.970 \\
\hline Organic matter\% & 1.080 & 1.100 \\
\hline $\mathrm{CaCO}_{3} \%$ & 6.050 & 6.090 \\
\hline Total N\% & 0.070 & 0.074 \\
\hline \multicolumn{3}{|c|}{ Available nutrients ( $\mathrm{mg} \mathrm{kg}^{-1}$ soil): } \\
\hline $\mathrm{K}$ & 70.15 & 72.10 \\
\hline $\mathrm{P}$ & 19.05 & 18.80 \\
\hline $\mathrm{Fe}$ & 6.52 & 6.10 \\
\hline $\mathrm{Mn}$ & 5.45 & 5.00 \\
\hline $\mathrm{Zn}$ & 1.15 & 1.05 \\
\hline $\mathrm{Cu}$ & 1.60 & 1.75 \\
\hline
\end{tabular}

The treatments were comprised of 4 ascorbic acid rates; 0 (control), 200, 400 and $600 \mathrm{mgl}^{-1}$. These treatments were applied alone or in combination with seed treatment with calcium paste.

Calcium nitrate, humic acid and wheat bran (a by-product of wheat grain) at the ratio of 1:1:3 (by weight), respectively were mixed and kneaded together by using Arabic Gum solution (8\%) as a sticking agent to obtain paste of calcium able to remaining around seeds to a longer time. Before sowing, cotton seeds were covered with calcium paste through the better mixing between them. Treated seeds were allowed to dry.

Chemical analysis of the most important components of humic acid and wheat bran was determined (Table 2) as outlined by A.O.A.C. (1995).

The experimental design used was a split-plot with three replicates. The main plots were calcium paste treated-seeds or untreated seeds. Ascorbic acid treatments occupied the sub-main plots. The experimental unit was $21 \mathrm{~m}^{2}(3 \times 7 \mathrm{~m})$. Seeds of cotton (cultivar Giza 90) obtained from the Agricultural Research Center, Giza, Egypt were sown ( $20 \mathrm{~cm}$ between hills) on March $21^{\text {st }}$ in both seasons. The cultural practices were applied as recommended for cotton production except for the variables under study. Three months after sowing, plants of four hills were randomly chosen from each experimental unit for determining the number of leaves plant ${ }^{-1}$, leaf area plant ${ }^{-1}$ and dry weight of leaves plant ${ }^{-1}$.

Leaves of plants submitted to vegetative growth trait were also subjected to chemical determinations. Chlorophyll a, chlorophyll $b$ and total carotenoids were extracted by acetone $(80 \%)$ then, their concentrations were determined using colorimetric method as described by Arnon (1949). Ascorbic acid ( $\mathrm{mg} \mathrm{g}^{-1}$ fresh leaves) was determined using the dye 2,6-dichlorophenol indophenols method as outlined by A.O.A.C. (1995). Total soluble sugars ( $\mathrm{mg} \mathrm{g}^{-1}$ dry matter) were colorimetrically determined using phosphomolybdic acid reagent according to Dubois et al. (1956). Free proline was extracted by 5 -sulphosalicylic acid (3\%) then, determined ( $\mathrm{mg} \mathrm{g}^{-1}$ dry matter) colorimetrically using acid ninhydrin reagent as outlined by Bates et al. (1973). Nitrogen (mg g ${ }^{-1}$ dry matter) was colorimetrically determined by using the Orange $\mathrm{G}$ dye according to the method of Hafez and Mikkelsen (1981). For P, K, Ca, Na, Fe, Mn and $\mathrm{Zn}$ determinations; the wet digestion of $0.1 \mathrm{~g}$ of fine dry material of leaves of each treatment was done with sulphuric and perchloric acid mixture as mentioned by Piper (1947). Phosphorus (\%) was colorimetrically estimated using chlorostannus molybdo-phosphoric blue color method in sulphuric acid system as described by Jackson (1967). Potassium and sodium (\%) were

Table (2): The most important constituents of humic acid and wheat bran used in the experiment of both seasons.

\begin{tabular}{|l|c|c|l|c|c|}
\hline \multicolumn{3}{|c|}{ Humic acid analysis \% } & \multicolumn{3}{c|}{ Wheat bran analysis } \\
\hline Main constituent & 2009 & 2010 & \multicolumn{1}{c|}{ Main constituent } & 2009 & 2010 \\
\hline Humic acid & 18.5 & 18.5 & Moisture\% & 4.50 & 4.30 \\
\hline Total Fe & 0.5 & 0.5 & Ash\% & 5.20 & 5.15 \\
\hline Total $\mathrm{Mn}$ & 0.5 & 0.5 & Total fibers\% & 35.45 & 36.25 \\
\hline Total $\mathrm{Zn}$ & 0.5 & 0.5 & $\begin{array}{l}\text { Water holding } \\
\text { capacity }\left(\mathrm{g} \mathrm{g}^{-1}\right)\end{array}$ & 3.35 & 3.40 \\
\hline Total $\mathrm{Cu}$ & 0.5 & 0.5 & &
\end{tabular}


determined using a Perkin-Elmer, Flame Photometer (Page et al., 1982). Calcium (\%), iron, manganese and zinc (ppm) were determined using a Perkin-Elmer, Model 3300, Atomic absorption Spectrophotometer (Chapman and Pratt, 1961). At harvest, the plants of four hills were randomly marked in each experimental unit to determine seed cotton yield and lint percentage. Designation and full details of experimentation are listed elsewhere (Dewdar and Rady, 2011).

The stepwise multiple regression and correlation analyses were carried out according to the procedures outlined by Draper and Smith (1966) to determine the variable which would account for the most variation in crop yield.

\section{RESULTS AND DISCUSSION}

\subsection{Analysis of variance}

The analysis of variance presented in Table (3) showed that the mean squares of regression analysis were highly significant for the nine acceptance variables out of eighteen ones (traits) i.e. number of leaves per plant, leaves area per plant, dry weight of leaves per plant, chlorophyll b, total carotenoids, phosphorus, iron, manganese and lint percentage, indicating that dependent variable (seed cotton yield) was affected by the nine acceptance variables (independent variables).

Table (3): Mean squares of regression analysis of stepwise technique in Egyptian cotton under saline conditions.

\begin{tabular}{|l|c|c|}
\hline S.V. & D.F. & M.S. \\
\hline Regression & 9 & $606.416^{* *}$ \\
\hline Residual & 14 & 1.294 \\
\hline
\end{tabular}

** Significant at $\mathbf{p}<0.01$ percent level of probability.

\subsection{Stepwise multiple regression analysis}

The results in Table (4) clarify that those nine traits i.e. number of leaves per plant, leaf area per plant, dry weight of leaves per plant, chlorophyll $\mathrm{b}$, total carotenoids, phosphorus, iron, manganese and lint percentage were significantly contributing to the variation in seed cotton yield per plant. The total contribution of the above mentioned characters over all variation in seed cotton yield per plant was $99.46 \%$. While, the residual effect of the other nine traits in seed cotton yield per plant was very small. It was reduced only $0.54 \%$ of the total variance. It is clear that the residual effect has slight importance contribution in cotton yield. The residual effect, which determines how best the causal variables account for the variability of the independent ariable was estimated by Singh and Chaudhary (1985). These results agree with those of El- Shear et al. (1984), Seyam et al. (1984) and Ghaly et al. (1990) who used the technique of stepwise multiple regression in Egyptian cotton.

\subsection{Correlation coefficients analysis}

The simple correlation coefficients between seed cotton yield per plant and the different variables are shown in Table (4). Cotton yield was positively correlated (highly significant) with the number of leaves per plant, leaf area per plant , dry weight of leaves per plant, chlorophyll $b$, total carotenoids, phosphorus, iron, manganese and lint percentage traits. Where their obtained values were $0.980,0.974,0.968,0.970,0.937,0.953$, $0.950,0.940$ and 0.923 , respectively. It seems therefore that the number of leaves per plant granted the highest value followed by leaf area per plant then chlorophyll $b$, while the lowest value was obtained from lint percentage. On the contrary, the other six traits ranked as the second in their values of correlation coefficients. These results agree with those obtained by Singh (2001), Reddy and Kuman (2004) and Gitelson et al. (2003), who reported significant and positive association between cotton yield and chlorophyll traits. Also, similar correlations were found between cotton yield and lint percentage by Karademir et al. (2009). Also, they added that the results of correlation coefficients analysis revealed that seed cotton yield per plant was positively and significantly correlated with chlorophyll content and lint percentage, as the increase in the two previously traits which may induced positive impacts on seed cotton yield under salinity stress conditions. Finally, the true picture of the correlation between seed cotton yield per plant and the acceptance traits under study is positively reflected from direct effect of these traits which will help for identifying the trait that contributes directly to improve cotton yield trait.

\subsection{Range and mean performances}

The results presented in Table (5) show the range and mean performances of the studied acceptance variables under salinity stress conditions. The results showed that the high increase in range might be attributed to the creation of variation via different treatments under study, whereas the number of treatments were eight (four rates of ascorbic acid; 0, 200,400 and $600 \mathrm{mgL}^{-1}$ and two calcium paste treatments ) provided a total of 8 treatments.

The obtained mean values were $38.30,49.24$, $22.03,0.65,0.41,0.35,474.70,283.13$ and 34.86 for the following traits: number of leaves per 
Table (4): Correlation coefficient, standard error and multiple coefficient of determination of nine various traits with seed cotton yield in Egyptian cotton.

\begin{tabular}{|l|c|c|c|}
\hline Parameter & $\begin{array}{c}\text { Correlation (r) } \\
\text { with seed cotton yield } \\
\text { per plant }\end{array}$ & Std. Error & Remarks \\
\hline Number of leaves per plant & 0.980 & 0.416 & H.S \\
\hline Leaves area per plant & 0.974 & 0.615 & H.S \\
\hline Dry weight of leaves per plant & 0.968 & 0.013 & H.S \\
\hline Chlorophyll b & 0.970 & 26.175 & H.S \\
\hline Total carotenoids & 0.937 & 23.881 & H.S \\
\hline Phosphorus & 0.953 & 24.153 & H.S \\
\hline Iron & 0.950 & 0.062 & H.S \\
\hline Manganese & 0.940 & 0.110 & H.S \\
\hline Lint percentage & 0.923 & 0.718 & H.S \\
\hline $\begin{array}{l}\text { Multiple coefficient of determination }=99.46 \\
\text { Residual = 0.54 }\end{array}$ & & \\
\hline
\end{tabular}

H.S. denotes highly significant for (r) values at ( $n-2)$ degree of freedom (df) against the table. values of correlation at $5 \%$ and $1 \%$ level of significance.

Table (5): Range and mean values of nine acceptance variables in Egyptian cotton under saline conditions.

\begin{tabular}{|l|c|c|c|}
\hline \multirow{2}{*}{\multicolumn{1}{|c|}{ Parameter }} & \multicolumn{2}{c|}{ Range } & \multirow{2}{*}{ Mean } \\
\cline { 2 - 3 } & Minimum & Maximum & \\
\hline Number of leaves per plant & 26.30 & 47.00 & 38.30 \\
\hline Leaves area per plant & 33.30 & 63.40 & 49.24 \\
\hline Dry weight of leaves per plant & 16.10 & 27.60 & 22.03 \\
\hline Chlorophyll b & 0.46 & 0.82 & 0.65 \\
\hline Total carotenoids & 0.29 & 0.53 & 0.41 \\
\hline Phosphorus & 0.23 & 0.48 & 0.35 \\
\hline Iron & 411.00 & 538.00 & 474.70 \\
\hline Manganese & 242.00 & 318.00 & 383.13 \\
\hline Lint percentage & 32.00 & 37.60 & 34.86 \\
\hline
\end{tabular}

plant, leaf area per plant, dry weight of leaves per plant, chlorophyll b, total carotenoids, phosphorus, iron, manganese and lint percentage, respectively. The standard error was the highest (26.175) for the chlorophyll b trait, whereas the lowest (0.013) for the dry weight of leaves per plant trait (Table 4).

In conclusion, this study was carried out under salinity stress condition, and showed significance for cotton yield and the three traits; number of leaves per plant, leaf area per plant and chlorophyll b. There is limited information between cotton yield and physiological parameters of cotton in the literature. Therefore, further investigation is required on cotton yield and physiological study.

The present regression and correlation analysis revealed that the number of leaves per plant, leaf area per plant and chlorophyll b may be an indication of seed cotton yield under salinity stress.

\section{REFERENCES}

A.O.A.C. (1995). Association of Official Analytical Chemists. Official Methods of Analysis. The Fifteenth Ed., Washington, D. C., USA.

Arnon D.I. (1949). Copper enzymes in isolated chloroplasts. Polyphenol-oxidase in (Beta vulgaris L.). Plant Physiol., 24: 1-5.

Bates L.S., Waldren R.P. and Teare I.D.(1973). Rapid determination of free proline for water stress studies. Plant and Soil, 39: 205207.

Chapman H.D. and Pratt P.F. (1961). Methods of Analysis for Soil, Plants and Water. Univ. Calif., D.V., Agric. Sci., USA.

Dewdar M.D.H. and Rady M.M. (2011). Urging cotton plants to overcome the salt stress conditions in the reclaimed land using a combination of innovative agricultural factors. Bull. Fac. Agric., Cairo Univ., 62: 161-172. 
Draper N. R. and Smith H. (1966). Applied regression analysis. John Willey and Sons. Inc, New York - 407 PP.

Dubois M.F., Gilles K.A., Hamiton J.K., Robers P.A. and Smith F. (1956). Colorimetric methods for determination of sugars and related substances. Anal. Chem., 28: 350354.

El-Shear M.H., Shabana M. R., El-Shiekh A.H. and Abdel-Rahman Laila M.A. (1984). Path coefficient analysis of some characters contribution to yield and quality of cotton. Agric. Res. Rev., 62 (6): 23 - 31.

Fonseca S. and Paterson F.M. (1968). Yield components heritability and interrelationship in winter wheat. Crop Sci., 8: 614-617.

Ghaly F., Thnan M., El-Gamal M., El-Banna M.H. and Antoun Samia D. (1990). Path coefficient analysis of some characters contribution using to yield variation of Giza 77 cotton cultivar. Agric. Res. Rev., 68(6): 1101-1109.

Gitelson A.A., Gritz Y. and Merzlyak M.N.(2003). Relationship between leaf chlorophyll content and spectral reflectance and algorithms for non- destructive chlorophyll assessment in higher plant leaves. J. Plant Physiol., 160: 271-282.

Hafez A.R. and Mikkelsen D.S. (1981). Colorimetric determination of nitrogen for evaluating the nutritional status of rice. Commun. Soil Sci. and Plant Analysis, 12(1): 61-69.

Jackson M.L. (1967). Soil Chemical Analysis. Prentice-Hall of India Private Limited, New Delhi, pp.144-197 and 326- 338.
Karademir C., Karademir E., Ekincl R. and Gencer O. (2009). Correlation and path coefficient analysis between leaf chlorophyll content, yield and yield components in cotton (Gossypium hirsutum L.) under drought stress conditions. Not. Bot. Agrobot. Cluj 37 (2): 241-244. (available online at www. notulaebotanicea. Ro).

Page A.I., Miller R.H. and Keeny D.R.(1982). Methods of Soil Analysis. Part II. Chemical and Microbiological Methods. The Second Ed. Amer. Soc. Agron., Madison, Wisconsin, USA.

Patrick D.B. (2007). Evaluating a chlorofhyll content meter on three coastal wetland plant species. J. of Agric., Food and Environ. Sci., 1(2): 1-11.

Piper C.S. (1947). Soil and Plant Analysis. The University of Adelaide, Adelaide, UK.

Reddy A.N. and Kuman S.R. (2004). Association of physiological parameters with yield and yield components in American Cotton (Gossypium hirsutum L.). Madras Agric. J.91(12 ):515-518.

Seyam S.M., Abo El-Zahab A.A., El-Rassas H.N. and El-Rayse F.M. (1984). The use of stepwise regression analysis in determining characters for yield selection in Egyptian cotton. Agric. Res. Rev. Vol., 62, No. (6) 41 $-47$.

Singh S.P.(2001). Broadening the genetic base of common bean cultivars .Crop Sci. 41: 16591675 .

Singh R. K. and Chaudhary B.D. (1985). Biometrical methods in quantitative genetic analysis. Kalyani Publishers, New Delhi, India.

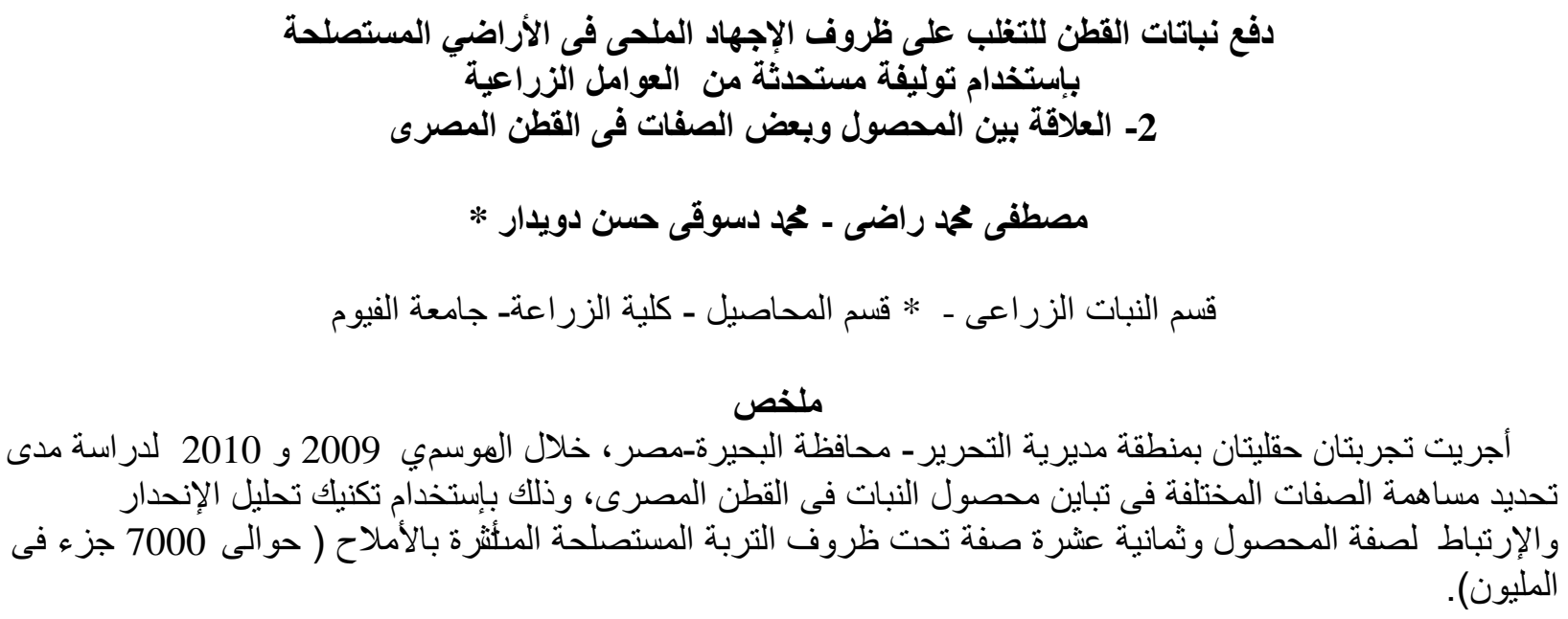


أوضح تحليل الإنحدار المتعدد المرحلي أن هناك إنحدار لتسعة صفات (تسعة عو امل) من بين ثمانية عشرة صفة (ثمانية

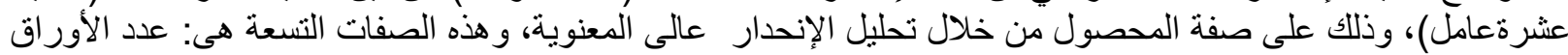

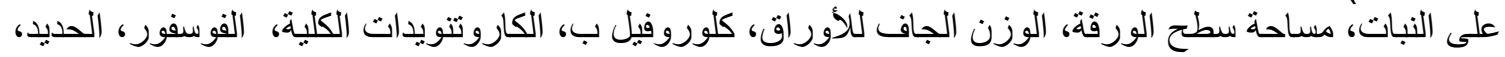

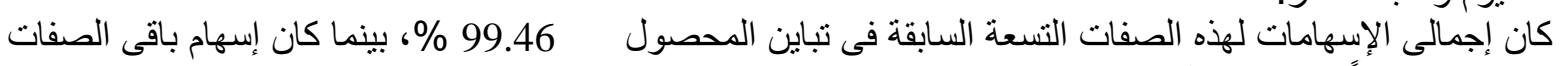

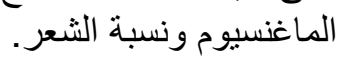

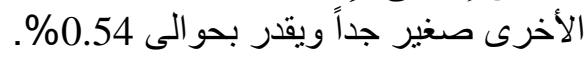

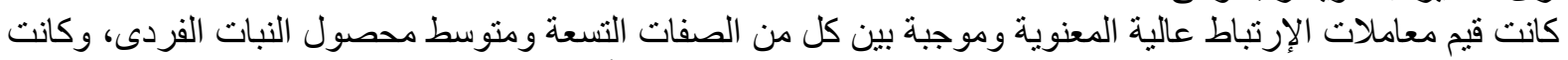

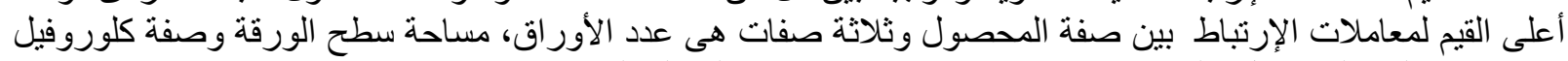

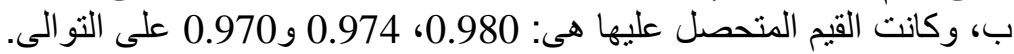
أنشارت النتائج إلى أن الزيادة الو اضحة واندة الملحوظة فى مدى منوسطات الصفات يرجع إلى تأثر هذه الصفات بالمعاملات المختلفة تحت الدر اسنة.

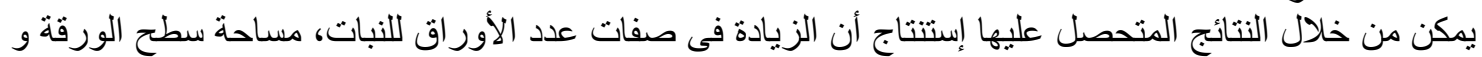

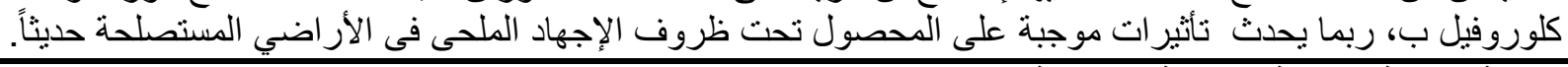

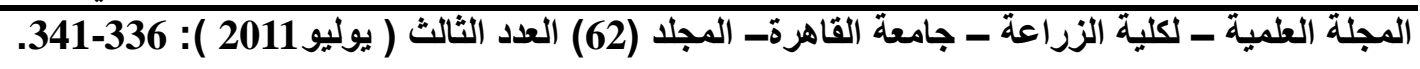

